upon either of the two remaining cards." The lower (15) being selected, and the remaining card (II) being turned up, this proved to be the card originally drawn.

Having seen this experiment twice made successfully with members of my family, I offered myself as the next "subject" of it, with the determination to watch carefully for any mar.ual guidance by which Mr. Bishop might be influencing my choice. The experiment succeeded with me as it had done with my predecessors, and yet I could not, any more than themselves, tell how I was led to make the five successive selections of the cards to be taken away, so as to leave behind the card I had originally drawn.

It may, of course, be assumed that Mr. Bishop knew where he had placed this card, although his "subject" did not; and he informed me that experience has taught him the positions to which the choice of his "subject" can be most easily and certainly guided. The influence of the eyes being excluded by the relative positions of Mr. Bishop and his "subject," the guidance must be conveyed through the hand which Mr. Bishop holds in his own; and yet I altogether failed to detect the mode in which it was given.

Of course it may be said that this is only a variation of the conjuror's trick of "forcing" the card which he has determined that the drawer shall choose. (I remember seeing it stated that Louis Napoleon, when Emperor, had defied Houdio then to "force" a card upon him; and that Houdin made him draw the card which in the French pack is designated Cæesar.) But though the same principle of "suggestion" is involved, the conditions under which it acts are altogether different. The conjuror stands opposite the drawer, looks at his face as well as at his hand, and continually shifts the position of the cards he holds, so as to prevent a wrong card from being drawn, while presenting the right one in the manner which he knows by experience to be the most suggestive. But Mr. Bishop does no such thing. The cards remain in their places with their faces downwards ; and of the guidance given him by Mr. Bishop standing at his side, the "subject"-even when on the watch for it-remains quite unaware.

If I have made myself understood by your readers, I think I shall have satisfied them that this "experiment" (which may by no means invariably succeed) is of great psychological interest, as showing the large measure in which we may be guided in our choice among things "indifferent," by influences of which we are ourselves unconscious. WILLIAM B. CARPENTER

\section{American Meteorological Observations}

IN your valued journal (vol. xxiv. p. I6) I find an expression of your regret that it should have been decided that the printing of the Bulletin of Simultaneous Meteorological Observations should hereafter take place one year after date, instead of six months. It may be interesting to those of your readers who made use of the Bulletin in studying the general atmospheric phenomena of the northern hemisphere, to know that for several years past the data for several distant land stations in Greenland, Iceland, Siberia, Alaska, \&c., have been omitted, merely because the mail facilities did not enable us to receive the reports in time for publication in the Bulletin. Thus a large portion of the region covered by our maps has been left unrepresented, for which the necessary data come regularly to hand a few weeks or months later. The case is still worse in reference to the marine reports for vessels off on long voyages; for instance, we regularly pay for and receive a large collection of material from the London Meteorological Office that never appears in our published Bulletin or charts. The proposed postponement of publication is in fact merely the outcome of several suggestions and recommendations from co-operating nation $\approx$, in the propriety of which recommendations myself and assistants fully concur.

W. B. HAZEN

Chief Signal Officer, U.S.A.

Office of the Chief Signal Officer, Washington, D.C., June 15

\section{A Meteor}

LAST night, June 24, at IIh. 29m. G.M.T., I observed a meteor, as bright as Jupiter, cross the tail of the great comet $4^{\circ}$ or $5^{\circ}$ above the head and disappear some $20^{\circ}$ to the left, on the vertical of Beta Ursæ Minoris and at an altitude equal to that of the comet's head. It left a bright streak for some seconds. I did not see the beginning, and perhaps not' the end, as it may have continued behind a cloud bank. The duration for the above path was three seconds, determined afterwards by experiment. Place of observation, lat. $51^{\circ} 32^{\prime}$, long. $0^{\circ} 1 \mathrm{I}^{\prime} \mathrm{W}$.

27, Hamilton Terrace, St. John's Wood, June 25

G. L. TUPMAN

LOOKING at the comet last night from my garden at II.25 p.m. I saw a large meteor pass nearly horizontally from a little east of north to within a short distance of the comet, rather above the head. It was as large as Venus when brilliant, but with a red or orange tinge. The motion was rather slow.

Adsett Court, Westbury-on-Severn, June 25

\section{Earthquake in Van}

IT may perhaps be considered worthy of a note in your columns that an earthquake was experienced in this neighbourhood on Monday, May 30 , at a few minutes before 6 a.m.

Here in Van the shock was slight, consisting only of a tremulous motion lasting a few séconds; but I have to day received information that at Bitlis the shock was so severe as to cause people to rush out of their houses in fright, and that a village named Téout, situated near the western shore of the Lake of Van, was destroyed by it, with the loss of a considerable number of lives. I have as yet heard no details, but if any further circumstances of interest should come to light I will communicate with you again.

It is well known that the environs of the Lake of Van show many signs of ancient volcanic action; at least three volcanoes with distinct craters forming prominent features on or near its shores. Of these the Nimrond Dagh, on the western shore of the lake, is said by tradition to have been active not more than 400 years ago. It contains an immense crater five or six miles across, in which are situated hot springs. The village Téout which has been destroyed lies at the foot of the eastern slopes of this mountain.

Van, Turkey in Asia, July 6 EMILIUS ClaytoN

\section{Freshwater Actinea}

I YESTERDAY noticed in a small freshwater aquarium four specimens of a small freshwater Actinia of a very pale olivaceous colour. They have each six tentacles more than $x$ inch in length when fully extended, but then so extremely fine at the ends as to be almost invisible. The body or stalk is about $0^{\prime} \mathbf{r}$ inch long by 0.05 inch in diameter when at rest, and about 0.5 inch long and 0.015 inch in diameter when expanded.

I was not aware before of the existence of freshwater Actinia, but as the specimens to which I now refer are in all respects similar to sea-anemones, there can be no doubt on the subject.

I have succeeded in transferring two specimens, which have duly rooted and expanded themselves in a bottle and a tumbler, and I shall be happy, if they are of sufficient interest, to send one to your office or elsewhere for inspection.

Royal Naval School, New Cross, June 24

\section{The Observation of Hailstorms}

In the most casual survey of the literature relating to the phenomenon of hail one cannot fail to be struck with the remark. able contradictions which everywhere make themselves apparent. Some writers say that hail falls oftenest in the tropics; others assert that it is altogether unknown there! Howard states that the maximum hailfall in this country occurs in the summer season, while Dalton and others say that it is in winter. I think these singular discrepancies are attributable, in many cases at least, to imperfect observations. Most of the meteorologists who have given special attention to the phenomenon of hail have had their pet theories, and naturally their observations have been guided to a considerable extent by the requirements of the particular theories which they advocated. Thus we find Kämtz ascribing the formation of hail to the conflict of opposing currents of wind, Volta to the electrical condition of two separate layers of cloud, Leslie to the presence of strata of air at different temperatures, von Buch to ascending currents of air, and so on, all which theories are based, not upon invariable phenomena, but upon isolated features which happen to have come repeatedly under the notice of those particular observers in the particular bailstorms which they witnessed. I think it would enhance the 